\title{
Thermomechanical Erosion Modelling of Baydaratskaya Bay, Russia with COSMOS
}

\author{
S.G. Pearson, R. Lubbad, \& T.M.H. Le \\ Sustainable Arctic Marine and Coastal Technology (SAMCoT), Centre for Research-based Innovation (CRI), \\ Norwegian University of Science and Technology (NTNU), Trondheim, Norway
}

R.B. Nairn

W.F. Baird \& Associates Coastal Engineers Ltd., Oakville, ON, Canada

\begin{abstract}
Rapid coastal erosion threatens Arctic coastal infrastructure, including communities and industrial installations. Erosion of permafrost depends on numerous processes, including thermal and mechanical behaviour of frozen and unfrozen soil, nearshore hydrodynamics, atmospheric forcing, and the presence of sea ice. The quantification and numerical modelling of these processes is essential to predicting Arctic coastal erosion. This paper presents a case study of Baydaratskaya Bay, Russia, using the COSMOS numerical model to predict thermal-mechanical erosion. In particular, this study focuses on thermoabrasional rather than thermodenudational processes. A field dataset of onshore thermal and mechanical soil characteristics was supplemented by sources from the literature to serve as input for the model. A detailed sensitivity analysis has been conducted to determine the influence of key parameters on coastal erosion rates at the study site. This case study highlights the need for expanded data collection on Arctic coastlines and provides direction for future investigations.
\end{abstract}

\section{INTRODUCTION}

\subsection{Background}

Climate change offers a daunting prospect for Arctic coastlines in the 21 st century. Longer open ice seasons, warmer sea temperatures, increased storminess and rising sea levels may compound already rapid coastal erosion rates.

In order to understand existing coastal morphodynamics in the Arctic and make predictions of future change, numerical modelling techniques may be employed. Application of existing tools and techniques developed for use in temperate climates may be limited by the unique physical processes influencing high-latitude coasts. On Arctic coasts, frozen sediment is subject to both thermal and mechanical effects. The thawing of frozen sediment by seawater and air makes it more vulnerable to wave action and hastens its removal from shore.

Nairn et al. (1998) identify three key factors which differentiate erosion of permafrost coastlines from those in temperate climates: (1) Melting of exposed frozen sediment by seawater. (2) Eroded material consisting of ice and fine sediment cannot be reconstituted in the littoral zone and thus will not contribute to the sediment balance. (3) Littoral zone subsidence due to melting.

Approximately two thirds of the Arctic coastline is composed of unlithified material vulnerable to erosion (Lantuit et al., 2013). The average rate of erosion in the Arctic is approximately $0.5 \mathrm{~m} /$ year, and $90 \%$ of the coastline experiences between 0-2 m of erosion annually (Lantuit et al., 2012). Local geology and climate also influence rates of coastline change, making its prediction a complex task.

Arctic coastal dynamics have increasing relevance in the 21 st century. Climate change is expected to decrease Arctic sea ice coverage, cause widespread permafrost degradation, and increase coastal erosion (Couture and Pollard, 2007, Barnhart et al., 2014). The convergence of natural changes and human development will threaten communities, infra-structure, and industry in the Arctic, as well as sites of cultural or historical significance.

Furthermore, the erosion of permafrost coastlines has also been linked to an increased flux of organic carbon into the Arctic Ocean and atmosphere (Lantuit et al., 2009). More accurate predictions of coastal erosion rates could yield better estimates of carbon flux for the purposes of improving oceanographic and climate models.

This paper examines thermo-mechanical erosion at Baydaratskaya Bay, Russia, using the COSMOS numerical model. In particular, this study focuses on thermoabrasional rather than thermodenudational processes. A field dataset of onshore thermal and mechanical soil characteristics was collected for the site and supplemented by sources from the literature to serve as input for the model. A sensitivity analysis has been conducted to determine the influence of 
key parameters on coastal erosion rates at the study site. This case study highlights the need for expanded data collection on Arctic coastlines and offers direction for future investigations.

\subsection{Environmental Forcing}

Multiple processes drive the erosion of Arctic coastlines, including sea ice, nearshore hydrodynamics, sea level change, and atmospheric and meteorological forcing. The many possible combinations of different coastline geometries and cryolithology and paucity of observational data make it extremely challenging to predict coastal erosion in the Arctic.

\subsubsection{Sea Ice}

Sea ice plays a complicated role in Arctic coastal erosion processes. On one hand, sea ice covers the sea surface for much of the year, preventing the generation of wind waves and the resulting erosion (Wegner et al., 2005). Sea ice typically forms during the fall and remains until early summer. In the icefree season, the coastline becomes exposed and is vulnerable to wave action. Hence, if recent trends continue (Forbes, 2011) and the duration or extent of open water is increased through climate change, the coast remains unprotected for longer and potential for erosion grows (Lantuit et al., 2012; Overeem et al., 2011)).

Conversely, the presence of sea ice can also serve as a mechanism of erosion and sediment transport through processes like ice bulldozing or entrainment by frazil ice (Are et al., 2008).

\subsubsection{Nearshore Hydrodynamics}

Hydrodynamic processes act on several different spatial and temporal scales, ranging from global (sea level rise, oceanic circulation) to regional (tides, storm surge) to local (waves, nearshore circulation).

Storm surge has a strong influence on coastal erosion. By exposing a greater area of coastal bluffs to wave attack and thermal degradation, it greatly accelerates the thermoerosion process (Lantuit et al., 2011; Overeem et al., 2011; Nairn et al., 1998). Furthermore, water level setup against the coastline can force strong offshore-directed currents that rapidly remove sediment from the nearshore area (Leont'yev, 2003). Much of the coastal permafrost erosion in the Arctic can be associated with these large storm surge events (Lantuit et al. 2011; Nairn et al. 1998).

Wind waves in the Arctic Ocean are characterized by their seasonality, sea ice-limited fetch, and the depth-limiting influence of the shallow seabed found in many coastal regions. The largest storms that influence coastal erosion tend to occur during the fall when sea ice cover is still in the early stages of growth (Overeem et al. 2011), since ice cover inhibits wave generation during winter storms. Leont'yev
(2003) observes that the shallow, gently sloping shelves offshore of many vulnerable Arctic coasts have a dissipative influence on incoming waves. Thus nearshore wave heights during extreme events may be depth-limited, but higher water levels due to storm surge could permit greater wave energy to reach the coast.

\subsubsection{Sea temperature \& Salinity}

Sea temperature is a key controlling variable for Arctic coastal erosion, since warm seawater degrades submarine permafrost in quiescent periods and drives thermoabrasion in storms. Specifically, it is the difference in temperature between seawater and melting point of the permafrost that determines the rate of erosion (Nairn et al. 1998). Lantuit et al (2012) find sea temperature to play a more prominent role in governing erosion than air temperature. Warm seawater enables thermoerosion to continue even during calm periods (Overduin et al., 2012).

Salinity plays a secondary role in Arctic coastal erosion as it governs the freezing temperature of seawater. Baird \& Associates (1995) found that typical seasonal variations in salinity did not have a major impact on thermal erosion rates.

\subsubsection{Sea Level Change}

Sea level change is relevant to Arctic coastal erosion in that rising water levels may increase vulnerability to coastal flooding, allow larger waves close to shore, and increase accommodation space for sediment. Global mean sea levels are projected to continue rising over the next century (Church et al., 2013), although the situation in the Arctic is complicated by the area's legacy of glaciation. Isostatic uplift may in some cases lead to localized sea level fall (Forbes, 2011). Conversely, relative sea level rise may also result from subsidence of the land. Wolfe et al (1998) found that thaw subsidence (wherein massive ground ice formations melt and cause lowering of the surface) was a major driver of erosion in the community of Tuktoyaktuk, Canada.

\subsubsection{Atmospheric \& Meteorological}

Atmospheric processes play a crucial role in the behaviour of Arctic coastal environments, especially in the response of permafrost to changes in thermal forcing. Air temperature is relevant to permafrost erosion in that convective heat transfer helps drive the thermodenudation and permafrost degradation process. Solar radiation drives thermoerosion through radiative heat transfer directly to the permafrost, but also by warming the seawater.

Snow has an insulating effect on permafrost, preventing freezing at greater depths but also delaying thaw. Snow cover protects the shore in early spring and summer, delaying the onset of thermodenudation, but can thaw and erode frozen sediment through nivation (Guégan \& Christiansen, 2016). 
Storms are typically weaker during the open ice season than winter (Serreze et al., 1993), although late summer storms like those observed in 2006 and 2012 (Simmonds \& Drinkwater, 2007; Simmonds \& Rudeva, 2012) have the potential to cause significant erosion to Arctic coasts.

\subsection{Geomorphology \& Cryology}

\subsubsection{Permafrost}

The key factor differentiating Arctic coastal dynamics from temperate locations is the presence of perennially frozen soil. The water normally present in soil freezes, changing the structure and properties of the soil with it.

Frozen soils are characterized by high strength and low permeability, properties which significantly influence their mechanical behaviour. Two key processes occur as soil freezes: volume expansion and segregation of ice lenses by cryosuction. The changes to the physical properties of frozen soil have implications for its strength and consequent behaviour in terms of slope stability, settlement, and erodibility. When frozen, the unconsolidated sediments have much higher mechanical strength, and must be thawed before they can erode (Are et al. 2008). Conversely, permafrost degrades when subject to warmer temperatures and solar radiation. During the thawing process, soils become more vulnerable to deformation and erosion. Furthermore, frozen soil is relatively impermeable and prevents drainage of melted water, thus increasing excess porewater pressures and decreasing shear strength of the soil (Yesuf et al., 2013).

Together, these thermal, hydraulic, and mechanical (THM) properties and processes drive Arctic geomorphologic changes, including solifluction, thermokarst formation, frost heave, differential settlement, and slope instability (Nishimura et al., 2009). Due to their influence on the strength and composition of soil, the formation and degradation of permafrost are essential processes in determining the erosion of Arctic coastlines.

\subsubsection{Ice \& Sediment Composition}

Sediment composition varies on Arctic coastlines from coarser gravel and sand beaches to fine silt and clay bluffs. The volume of coarse sediment in a coastal profile determines beach erosion rates (Kobayashi et al. 1999), since ice and fine material cannot be reconstituted in their original form and are effectively lost from the littoral sediment budget. Only coarse sediment can form bars and beaches to protect the shore. Hence, coastlines with high ice content and fine content are correlated with higher rates of erosion (Lantuit et al., 2012; Are \& Reimnitz, 2008). Variations in sediment and ice composition along the coastline will subsequently lead to variations in erosion rates. In general, ice content exerts a strong positive influence on erosion rates (Barnhart, Overeem, et al., 2014; Kobayashi et al., 1999)

\subsubsection{Submarine Permafrost}

The influence of permafrost also extends beyond the land to the coastal seabed. Coastal erosion is controlled by the shape, depth, slope, and sediment characteristics of the shoreface, so submarine permafrost may also play a role in the unique behaviour of Arctic coastlines. Nairn et al. (1998) suggest that the main driver of thermoabrasional erosion is underwater erosion of the shore profile (seabed downcutting). Further compounding this problem is thaw subsidence from melting submerged permafrost (Are et al. 2008). Deepening of the nearshore profile allows larger waves to reach the bluff, increasing the potential for erosion. It is thus important for Arctic coastal erosion studies to characterize the properties of frozen soil not just on land, but also in the nearshore zone.

\subsection{Thermoerosional Processes}

In temperate climates, coastal erosion is linked to the mechanical action of waves and currents, with influence from mechanical, chemical, and biological weathering. However in high latitudes, there is also a thermal component to the erosion process. The two main erosion processes for such coastlines are called thermodenudation and thermoabrasion, and are differentiated by the relative influence of thermal and mechanical factors. While thermodenudation results from gradual thawing in quiet conditions, thermoabrasion is driven by high-energy storms.

\subsubsection{Thermodenudation}

A frozen bluff gradually thaws under the influence of warmer air temperatures, solar radiation, and snowmelt (Guégan \& Christiansen, 2016), losing its strength in the process. It gradually becomes unstable and eventually fails, depositing scree at the base of the slope. This thawed, unconsolidated material is then available for removal by waves and currents (Lantuit et al. 2011).

Thermodenudation is most common in coastlines with high ice and fine sediment content. It tends to occur during calm conditions, which are more typical in the early open water season when there are fewer storms (Overeem et al. 2011). As such, it is a thermally rather than mechanically-dominated process, and the seawater has little to no direct contact with permafrost (Lantuit et al. 2013; Are et al. 2008). The failure debris can significantly delay the direct wave attack of the bluff (Baird \& Associates 1995), and its removal is comparable to erosion in temperate zones (Lantuit et al. 2013). As such, it is possible that existing methods of predicting erosion 
can be used to model the removal of the failed sediment.

\subsubsection{Thermoabrasion}

Whereas thermodenudation tends to dominate in calm conditions, thawed sediment may be removed faster than the frozen sediment can be melted during storms. This exposes the frozen sediment directly to the mechanical and thermal action of seawater in a process known as thermoabrasion (Günther et al., 2012; Nairn et al., 1998; Are et al., 2008). Without significant wave action, the unfrozen sediment will insulate the frozen material beneath, greatly limiting the severity of thermoabrasion (Kobayashi \& Aktan, 1986; Kobayashi et al., 1999).

With warmer, turbulent seawater in direct contact with the frozen soil, it thaws quickly via convective heat transfer, melting the interstitial ice matrix that bonds sediment particles together (Wobus et al., 2011; Lantuit et al., 2013; Overeem et al., 2011). The temperature difference between the seawater and sediment is a key factor in determining the rate of cliff retreat (Kobayashi et al. 1999). Fine material and melted ice are then moved offshore and effectively removed from the littoral system (Nairn et al. 1998; Kobayashi \& Aktan 1986).

This rapid thawing and removal of sediment can result in the formation of horizontal notches in the frozen bluff face (Overeem et al. 2011). Eventually the mass of the overhanging bluff exceeds the shear or bending strength of the soil, and the bluff face collapses as a massive block (Hoque \& Pollard 2009; Ravens et al. 2012; Wobus et al. 2011; Barnhart, Anderson, et al. 2014).

\subsubsection{Relative Influence of Thermoerosion}

Effective prediction of coastal retreat in the Arctic will rely on a clear understanding of when and where thermodenudation or thermoabrasion dominates for a given site. Thermodenudation is controlled by subaerial and underwater conductive heat transfer through thawed sediment, whereas thermoabrasion is governed by convective heat transfer from warm, turbulent seawater directly to exposed frozen sediment. Numerous factor may influence the dominance of a given process, including time of year, sea ice, snow, solar radiation and air temperature, sea water temperature, waves, ice content, and geology (Günther et al., 2012). Both processes may act at the same site over different time scales, with thermodenudation dominating quiescent periods and thermoabrasion occurring episodically during storms.

\section{SITE DESCRIPTION}

Baydaratskaya Bay is a shallow Russian gulf located at the southwest margin of the Kara Sea (Figure 1).
The region is sparsely populated with few roads or settlements, and the harsh climate and re-mote location make access to the study site challenging. The Nord-Stream gas pipeline was constructed across Baydaratskaya Bay in 2011 (Ogorodov et al., 2013), making landfall along the west coast, approximately $85 \mathrm{~km}$ southeast of Ust-Kara (68 $\left.51^{\circ} \mathrm{N}, 66^{\circ} 47^{\prime} \mathrm{E}\right)$. The threat of coastal erosion to the pipe-line landfall provides motivation for understanding the processes at work there.

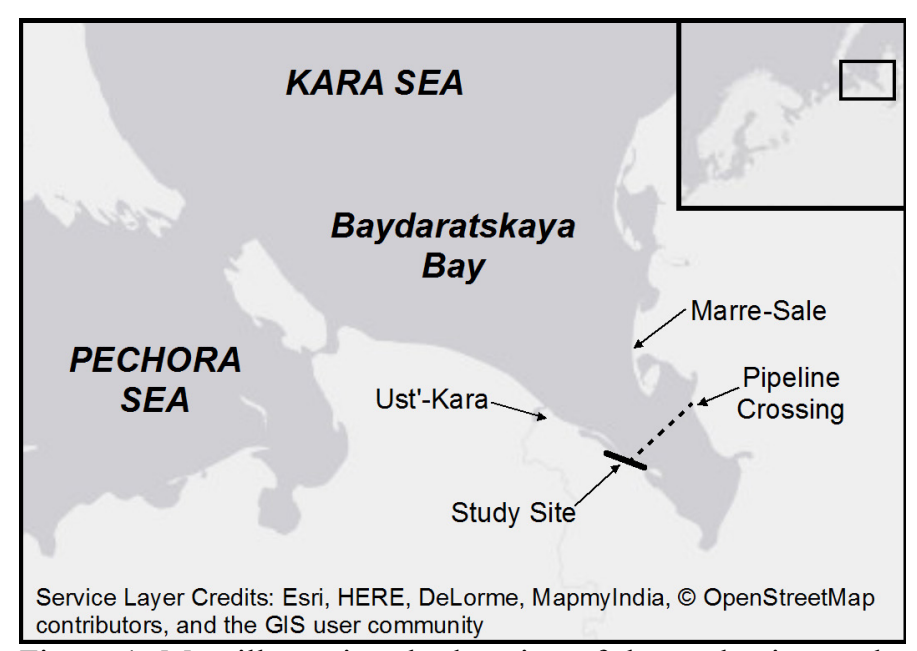

Figure 1. Map illustrating the location of the study site on the western coast of Baydaratskaya Bay, Russia.

Baydaratskaya Bay was formed as a glacial depression during the Late Pleistocene and then submerged in the Holocene (Levitan \& Lavrushin, 2009). The coastal sediment largely consists of consolidated silty clays with sand, gravel, and peat lenses. Massive ground ice bodies up to $7 \mathrm{~m}$ thick are also present along the coastline (Belova et al., 1998). Seabed permafrost may extend to a depth of at least $25 \mathrm{~m}$ (Osterkamp \& Romanovsky, 1997). The seabed slope is shallow, between 0.004-0.01 in the nearshore (Kamalov et al., 2006; Bogorodskii et al., 2010), and the maximum depth in the bay is approximately $23 \mathrm{~m}$ (Ogorodov et al., 2013).

Sea ice typically forms on the bay in mid-late October and reaches an annual maximum thickness of $1.2 \mathrm{~m}$ at the west coast of the bay (Ogodorov et al., 2013). The length of the ice-free season on the West Kara Sea has extended by approximately 34 days between 1979-2006 (Rodrigues, 2008). Seabed gouging due to ice ridges and icebergs has been observed even in the deepest portions of the bay $(23 \mathrm{~m})$, and the nearshore zone is also subject to mechanical action by landfast ice (Ogorodov et al., 2013).

The oceanographic properties of Baydaratskaya Bay are influenced by inflow through the Kara Strait from the Barents Sea, which brings warmer, saltier water into the bay. This inhibits thermohaline stratification and typically keeps the bay ice-free until later in the autumn than other parts of the Kara Sea (Harms \& Karcher, 1999). Sea surface temperatures reach their maximum in August at approximately 6$7^{\circ} \mathrm{C}$ (Harms \& Karcher, 1999). The salinity of the 
bay depends mainly on inflow from the Barents Sea, brine release due to ice formation, and freshwater input from rivers or melting ice. The bay typically has a salinity ranging from 20-25 ppt (Pivovarov et al., 2003). Baydaratskaya Bay has a tidal range of 70 $\mathrm{cm}$, leading to currents in excess of $30 \mathrm{~cm} / \mathrm{s}$ (Harms \& Karcher, 1999).

The annual mean air temperature at Marre Sale (located on the eastern side of Baydaratskaya Bay) from $1961-1990$ was $-8.3^{\circ} \mathrm{C}$, with mean January and July air temperatures of $-22.4^{\circ} \mathrm{C}$ and $7.1^{\circ} \mathrm{C}$, respectively (Goryainov \& Kryjov, 2000). Annual precipitation ranges from 300-500 $\mathrm{mm} /$ year, and thick snowbanks typically accumulate at the toe of coastal bluffs (Aleksyutina et al., 2013). Winds during the ice-free season (June to September) are typically weak, but strengthen in October to December (Harms \& Karcher, 1999), giving the strongest potential for erosive wave and surge conditions.

Leont'yev (2003) suggests that storm surges can reach up to $2 \mathrm{~m}$ and that the average annual maximum root-mean-square wave height $\left(\mathrm{H}_{\mathrm{rms}}\right)$ is 1.3-1.8 $\mathrm{m}$, with peak periods $\left(\mathrm{T}_{\mathrm{p}}\right)$ between 5-6 seconds. No long or short-term wave statistics are available for the site.

Historical rates of recession at the site vary from 0.5-1.5 m/year (Leont'yev \& Rachold, 2005), and up to $5-10 \mathrm{~m} /$ year for locations with significant ground ice deposits (Ogorodov et al., 2013). Both thermodenudation and thermoabrasion processes act on the site to varying degrees.

\section{METHODOLOGY}

In order to predict future erosion rates at the study site, we applied a coastal profile model using measured geotechnical data and sources in the literature. Due to limited availability of metocean and nearshore data, a sensitivity analysis approach was chosen to characterize the dominant processes at the site and inform future investigations.

\subsection{Modelling Approach}

Numerical models are instrumental in understanding the physical processes involved in Arctic coastal erosion and can be used to quantify and predict its effects. Most coastal engineering models developed for temperate climates are insufficient for predicting Arctic coastal erosion since they do not account for the thermal processes involved. However, they may still be useful as inputs for dedicated thermoerosion models by simulating processes like sediment transport, hydrodynamics, or ice coverage at larger scales.

Several studies have developed detailed models of thermomechanical block erosion using observations from the Alaskan coast (Barnhart, Anderson, et al., 2014; Hoque \& Pollard, 2009; Ravens et al., 2012). Leont'yev (2003; 2004) developed a morphodynamic profile model for decadal predictions of erosion at several sites in the Russian Arctic. However, the model did not directly account for thermal processes, assuming the net shoreline change to be controlled more by mechanical action of waves.

To describe the complex interactions of soil, ice, and unfrozen water, a thermo-hydro-mechanical (THM) model can be used (Nishimura et al., 2009; Thomas et al., 2009). These models consider elastoplastic mechanical behaviour of frozen and unfrozen soil and processes like cryosuction, two-sided freezing, and the formation of ice lenses. This enables the thaw-related mass wasting processes in thermodenudation to be simulated.

\subsection{COSMOS Model}

This study relies on the coastal profile model COSMOS for the prediction of thermoabrasion. It was developed as a deterministic process-based hydrodynamic and sediment transport model by Nairn \& Southgate (1993a; 1993b). The hydrodynamic component models waves, currents for $1 \mathrm{D}$ profiles on alongshore uniform coastlines.

The sediment transport module represents both alongshore and cross-shore transport processes. COSMOS uses an adapted Energetics approach to wave-induced sediment transport and the van Rijn approach to tidal current transport. It has been developed to model the erosion of cohesive bluffs, and was validated using laboratory experiments and data from the field (Nairn \& Southgate, 1993). COSMOS describes downcutting of cohesive shorelines due to bed shear stress from wave orbital velocity, and energy dissipation due to wave breaking.

In addition to hydrodynamic and sediment transport processes, COSMOS is also capable of simulating thermo-mechanical erosion of frozen soils. This module was developed for use in the Canadian Arctic (Nairn et al. 1998; Baird \& Associates 1995) using the method of Kobayashi \& Aktan (1986) for thermoabrasion. A full description of the thermo-mechanical module can be found in (Nairn et al. 1998; Kobayashi et al. 1999; Baird \& Associates 1995).

COSMOS treats the soil as existing in two discrete states: frozen and unfrozen. The fraction of coarse sediment can be specified, which is important for determining the amount of material that remains in the littoral zone and the amount that is lost offshore (fine sediment and melted ice). The depth to the frozen layer (corresponding to the thickness of the active layer) is provided as input for the model, and it is thawed by conduction through unfrozen soil or directly through convective heat transfer by warm, turbulent seawater (thermoabrasion). 
The thermal erosion module of COSMOS was developed and tested on sites on the Canadian Beaufort Sea coast (Kobayashi et al. 1999; Nairn et al. 1998; Baird \& Associates 1995). The model was able to successfully predict erosion of Arctic coastal bluffs and a barrier spit due to storm events (Nairn et al. 1998).

\subsection{Sensitivity Analysis}

A field measurement campaign reported in Aleksyutina et al (2013) focused mainly on thermodenudation processes, characterizing the middle and upper portions of the bluff in Baydaratskaya. Boreholes yielded information on the grain size characteristics and stratigraphy of the bluffs, and in-situ thermistors were used to measure changes in soil temperature as a function of depth and time. However, to model thermoabrasion, metocean conditions, subsea permafrost and sediment characteristics, and nearshore bathymetry are all required. Furthermore, thermoabrasion is episodic, so immediate pre- and post-storm surveys are essential to discerning the impact of a particular event from other more gradual processes like thermodenudation. In the absence of measured data for these input parameters, a sensitivity analysis was undertaken to explore the applicability of COSMOS to the study site.

An idealized one-dimensional coastal profile was used as the basis for modelling (Figure 3). 239 different scenarios were simulated in COSMOS, each altering a single parameter from a base case. With the exception of wave height and period, interactions between input variables are not considered. The combined influence of wave height and period was examined by expressing the two variables in terms of the Iribarren number $\left(\xi=\tan \alpha /\left(\mathrm{H}_{0} \mathrm{~L}_{0}\right)^{1 / 2}\right)$, where $\tan \alpha$ is the seabed slope, $\mathrm{H}_{0}$ is the offshore wave height, and $\mathrm{L}_{0}=\mathrm{gT}^{2} / 2 \pi$ is the deep water wavelength. $\xi$ is less than 0.5 for all tested cases, placing the site firmly in a dissipative regime with spilling breakers.

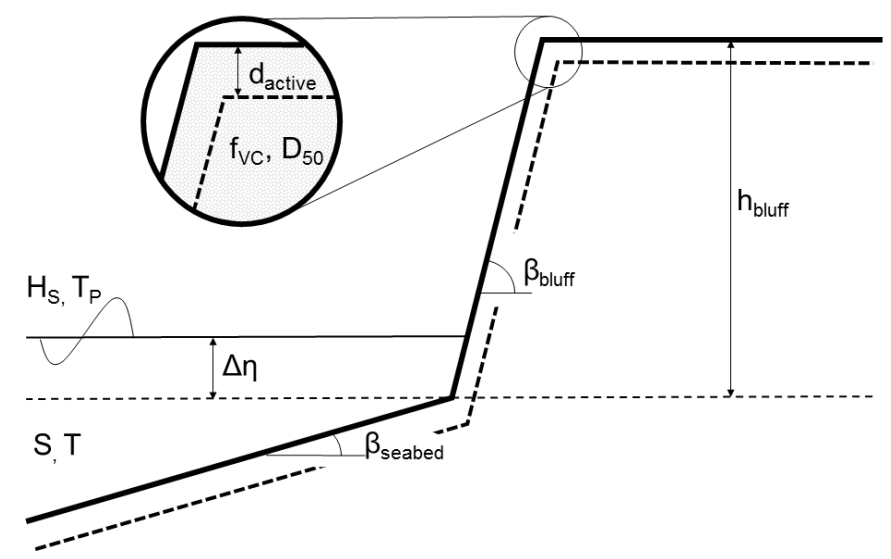

Figure 3. Schematic of COSMOS model setup for sensitivity analysis.

The parameter space was defined using typical site characteristics from the field investigations re- ported in (Aleksyutina et al., 2013) and the aforementioned sources in the literature (Table 1).

Table 1. Parameter space for model sensitivity analysis based on typical characteristics of Western Baydaratskaya Bay coastline.

\begin{tabular}{lllll}
\hline Parameter & Units & $\begin{array}{l}\text { Lower } \\
\text { Bound }\end{array}$ & $\begin{array}{l}\text { Base } \\
\text { Case }\end{array}$ & $\begin{array}{l}\text { Upper } \\
\text { Bound }\end{array}$ \\
\hline $\mathrm{h}_{\text {bluff }}$ & $\mathrm{m}$ & 6.0 & 12.0 & 20.0 \\
$\beta_{\text {bluff }}$ & - & 0.20 & 0.50 & 1.00 \\
$\beta_{\text {seabed }}$ & - & 0.001 & 0.006 & 0.015 \\
$\mathrm{f}_{\mathrm{vc}}$ & - & 0.00 & 0.10 & 0.60 \\
$\mathrm{D}_{50}$ & $\mu \mathrm{m}$ & 70 & 100 & 2000 \\
$\mathrm{~d}_{\mathrm{active}}$ & $\mathrm{m}$ & 0.00 & 0.75 & 1.50 \\
$\mathrm{~S}$ & $\mathrm{ppt}$ & 0 & 35 & 35 \\
$\mathrm{~T}$ & ${ }^{\circ} \mathrm{C}$ & 0 & 5 & 10 \\
$\Delta \eta$ & $\mathrm{m}$ & -0.50 & 1.00 & 3.00 \\
$\mathrm{H}_{\mathrm{s}}$ & $\mathrm{m}$ & 0.50 & 1.50 & 3.00 \\
$\mathrm{~T}_{\mathrm{p}}$ & $\mathrm{s}$ & 5 & 6 & 12 \\
\hline
\end{tabular}

Where $h_{\text {bluff }}=$ bluff height; $\beta_{\text {bluff }}=$ bluff slope; $\beta_{\text {seabed }}=$ seabed slope; $f_{\mathrm{vc}}=$ fraction of coarse sediment; $\mathrm{D}_{50}=$ median grain size; $\mathrm{d}_{\text {active }}=$ active layer thickness; $\mathrm{S}=$ sea salinity; $\mathrm{T}=$ sea temperature; $\Delta \eta$ = water level above the bluff toe; $\mathrm{H}_{\mathrm{s}}=$ significant wave height; and $\mathrm{T}_{\mathrm{p}}=$ peak wave period.

There were no tidal currents or variations in water level over the simulation period. A range of water levels $(\Delta \eta)$ from $-0.50-3.00 \mathrm{~m}$ were considered, allowing for the combined effects of tides and storm surge. Normally incident waves were selected in the absence of measured directional wave data for the site. COSMOS is a spectrally averaged model with significant wave height and peak wave period specified. Significant wave heights from 0.5 to $3.0 \mathrm{~m}$ were simulated in combination with periods from 5 to $12 \mathrm{~s}$. Wave conditions were assumed to be constant for the duration of the 24 hour simulation period.

The model domain extends $2000 \mathrm{~m}$ offshore to a depth of $12 \mathrm{~m}$, with grid spacing varying from $100 \mathrm{~m}$ at the offshore boundary up to $0.25 \mathrm{~m}$ in the nearshore and at the bluff. In the absence of nearshore bathymetric data, idealized profiles of constant seabed and bluff slopes were developed based on typical gradients for the region. Bluff height was varied to represent the range of heights observed in the study area.

The depth to frozen soil (active depth) was based on thermistor temperature profiles measured in boreholes along top of the bluff (Aleksyutina et al., 2013). Active depth varies seasonally from a maximum of $1.3 \mathrm{~m}$ in late summer to a minimum of $0 \mathrm{~m}$ in winter. Since no measurements of subsea permafrost were available, active depth was assumed to be constant across the profile.

Grain size characteristics were also obtained from these boreholes. The sediment profiles indicate predominantly fine materials interspersed by layers of 
sand $(80-90 \%$ fines). In COSMOS, the fraction of coarse material is specified to distinguish beachforming sediment from fine sediment and ground ice that will be lost from the littoral system. $\mathrm{A} \mathrm{d}_{50}$ of $100 \mu \mathrm{m}$ was used to represent coarse sediment material, and held constant across the profile in the absence of measured grain sizes for the beach or nearshore. Due to the strong cohesion of sediment in the bluff, the process of avalanching beyond a critical slope angle was disabled.

The model is not able to simulate the long-term subaerial thawing and slope failures central to the thermodenudation process, and the direct morphological effects of sea ice were considered beyond the scope of the present study. Unknown model parameters and constants were defined based on calibrated values for similar thermoabrasive sites in the Canadian Arctic (Baird \& Associates, 1995).

\section{RESULTS}

\subsection{Base Case}

As an example, pre- and post-storm profiles for the base case are provided in (Figure 4). COSMOS has a 1D horizontal computational grid, and as such cannot directly represent the lateral undercutting process of notch formation. Nonetheless, a vertical scour hole forms, which may be used as a proxy for notch depth, given the equivalent energy dissipation at the toe of the bluff. (Baird \& Associates, 1995). Thus scour hole depth $\left(\Delta z_{\text {notch }}\right)$ and lateral retreat of the bluff $\left(\Delta \mathrm{x}_{\text {toe }}\right)$ are used as an indication of the degree of thermoabrasion.

Base Case - Duration: $24 \mathrm{hr}$

Niche Depth $=-2.99 \mathrm{~m}$ Toe Retreat $=-4.80 \mathrm{~m}$

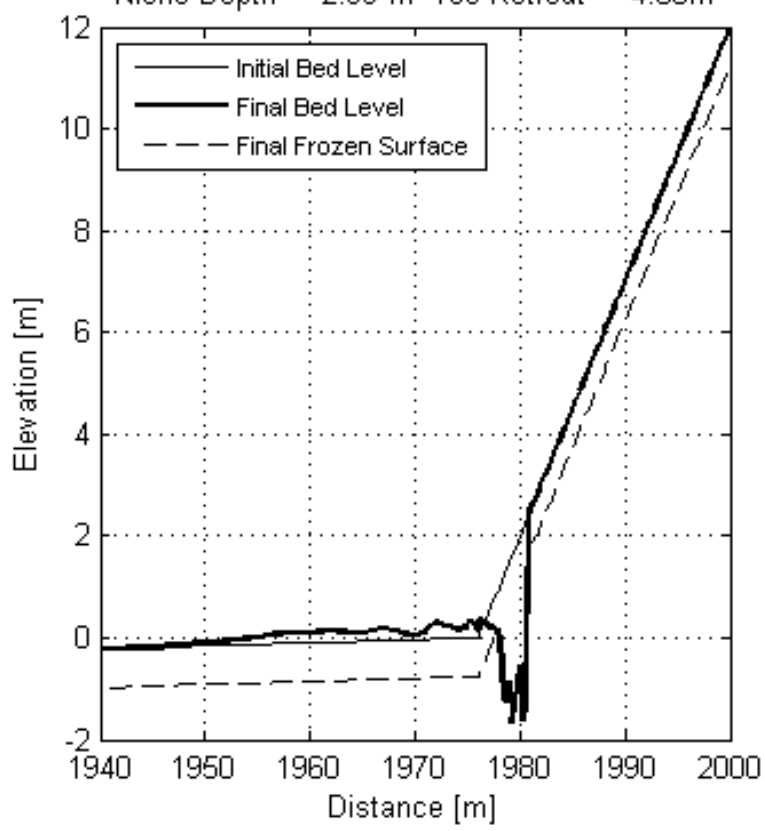

Figure 4. COSMOS post-storm profile for base case of sensitivity analysis.

Notch depth $(2.99 \mathrm{~m})$ is given as the maximum cumulative lowering of the frozen subsoil surface across the profile, and toe retreat $(4.8 \mathrm{~m})$ indicates the lateral migration of the bluff toe at $0 \mathrm{~m}$ elevation. A series of small bars form seaward of the scour hole, and the seabed lowers by an average of $0.04 \mathrm{~m}$ between 50-500 $\mathrm{m}$ offshore due to wave energy dissipation by breaking.

\subsection{Sensitivity Analysis}

To quantify model sensitivity, notch depth and toe retreat were compared (Table 2). The relative change from the base case across the tested parameter space, i.e. $\left(\Delta \mathrm{x}_{\text {toe (max/min) }}-\Delta \mathrm{x}_{\text {toe (base case) }}\right) / \Delta \mathrm{x}_{\text {toe (base case) }}$ is used as an indication of model sensitivity, and the linear correlation $(R)$ is given.

Table 1. Model sensitivity to changes in each parameter.

\begin{tabular}{lllllll}
\hline & \multicolumn{3}{l}{ Toe Retreat $\left(\Delta \mathrm{x}_{\text {toe }}\right)$} & \multicolumn{3}{l}{ Notch Depth $\left(\Delta \mathrm{z}_{\text {notch }}\right)$} \\
\cline { 2 - 7 } & $-\%$ & $+\%$ & $\mathrm{R}$ & $-\%$ & $+\%$ & $\mathrm{R}$ \\
\hline $\mathrm{h}_{\text {bluff }}$ & -27.1 & 25.0 & 0.937 & -18.3 & 22.4 & 0.441 \\
$\beta_{\text {bluff }}$ & -47.9 & 87.5 & -0.858 & -99.5 & 27.5 & 0.716 \\
$\beta_{\text {seabed }}$ & -27.1 & 20.8 & 0.913 & -13.1 & 24.3 & 0.926 \\
$\mathrm{f}_{\mathrm{vc}}$ & -100.0 & 0.0 & -0.689 & -57.5 & 0.0 & -0.971 \\
$\mathrm{D}_{50}$ & -100.0 & 0.0 & -0.654 & -99.6 & 25.8 & -0.642 \\
$\mathrm{~d}_{\text {active }}$ & 0.0 & 0.0 & 0.000 & -25.6 & 12.1 & -0.686 \\
$\mathrm{~S}$ & 0.0 & 0.0 & 0.000 & -5.9 & 8.2 & 0.039 \\
$\mathrm{~T}$ & 0.0 & 0.0 & 0.000 & -16.8 & 14.6 & 0.901 \\
$\Delta \eta$ & -100.0 & 145.8 & 0.985 & -99.6 & 153.5 & 0.975 \\
$\mathrm{H}_{\mathrm{s}}$ & -100.0 & 14.6 & 0.637 & -99.4 & 46.9 & 0.882 \\
$\mathrm{~T}_{\mathrm{p}}$ & -1.000 & 0.146 & -0.052 & -0.994 & 0.469 & -0.279 \\
$\xi$ & -1.000 & 0.146 & -0.628 & -0.994 & 0.469 & -0.833 \\
\hline
\end{tabular}

The largest notch depth comes from higher water levels, larger waves, and reduced coarse fractions, which suggests that storm surge conditions affecting ice-rich, fine sediment bluffs could cause the most significant erosion rates. The largest toe retreat comes from higher water levels, gentler bluff slopes, higher bluffs, and steeper seabed slopes. Whether due to storm surge, high tide, steep seabed slopes, or profile downcutting, deeper water at the bluff toe enables larger waves to reach the bluff, increasing the modelled erosion rates.

No retreat was observed for smaller waves, lower water levels, and largest grain sizes. There is very little retreat at low water levels because the majority of wave energy is dissipated on the foreshore and beach rather than on the bluff. As the fraction of coarse sediment and grain size increase, a larger beach builds out in front of the bluff, protecting it from further wave action. Steeper bluff slopes decrease the rate of toe retreat but increase the notching depth, likely as a result of wave reflection.

Salinity and temperature exert a negligible influence on toe retreat rates. There is a minor increase in notch depth with temperature, although salinity has limited influence. Hence, coastal erosion may be less sensitive to seasonal fluctuations in salinity associated with the spring freshet. 
Nearshore profile downcutting increases significantly for scenarios with thin active layers, suggesting that the characterization of subsea permafrost may be important. The presence of a thawed layer of sediment acts as an effective buffer against rapid thermoabrasion processes. Seasonal variations in active depth and storm conditions may offset each other, since thawing is deeper in the late summer and early fall when stronger forcing occurs.

Notch depth tends to increase for decreases in $\xi$, suggesting that more dissipative conditions may lead to greater thermoabrasion.

\section{DISCUSSION}

This case should thus be viewed as a proof-ofconcept study, which demonstrates the use of COSMOS as a thermoabrasional model in a data-poor environment. It highlights the data needs for meaningful predictions of Arctic coastal erosion, and gives direction for future investigations.

The model suggests that thermoabrasion is most sensitive to water level, which underscores the threat posed by relative sea level rise. This corroborates with findings in the literature that link accelerated erosion to high storm surges (Kobayashi et al., 1999; Leont'yev, 2003; Barnhart, Overeem, et al., 2014). The more sensitive variables (i.e. water level, wave characteristics, and profile geometry) should be the highest priority for future data collection efforts.

In particular, annual profile surveys extending out to the lower shoreface will provide a valuable dataset for understanding long-term Arctic coastal dynamics. This field work could be supplemented by laboratory experiments to calibrate and validate numerical models of permafrost erosion, similar to Skafel \& Bishop's work on cohesive sediment (1994).

Given the limited availability of Arctic coastal erosion data and challenges associated with data collection in cold climates, innovative measurement techniques could be used. For instance, seismic monitoring of cliff motion, time-lapse cameras, drone-based photography and LiDAR, portable freefall penetrometers, and geoelectric measurements have all been used successfully to obtain relevant coastal datasets. Combinations of the above sources can be used with conventional measurements to paint a more complete picture upon which to base our understanding of Arctic coastal dynamics.

Without observations of the hydrodynamics and timing of erosion events, it is difficult to accurately model erosion of frozen coastlines. Over what timescale do observed erosion rates occur? Separating the relative influence of episodic storms (thermoabrasion) and gradual deterioration (thermodenudation) is key to understanding the specific mechanisms of each process. Hence, to satisfactorily predict erosion of Arctic coastlines, modelling techniques must be able to account for the full range of processes involved over multiple spatial and temporal scales.

Existing hydrodynamic and thermo-hydromechanical models could also be coupled to capture full range of thermoerosion processes (thermoabrasion and thermodenudation). Furthermore, probabilistic approaches such as Monte Carlo simulation or Bayesian network modelling could be used to account for the uncertainty in the available and missing data.

Dissipative beaches like this study site are dominated by infragravity energy (Wright et al., 1982). Infragravity waves (characterized by periods in the range of 30-300s) have been little studied in the context of Arctic coastal erosion. However, it may be possible to hypothesize their role by drawing analogy to their behaviour in temperate seas. Infragravity waves form by way of nonlinear interactions between higher-frequency waves, and may become freed or trapped in the nearshore. These long waves are greatest in height at the shoreline and can amplify short wave height by effectively increasing local water depth (Beetham \& Kench, 2011). Higher levels of wave energy can thus reach the shore and lead to greater erosion.

Infragravity waves play a crucial role in dune erosion, driving swash processes and inducing dune face avalanching (Roelvink et al., 2009). The onshore mass flux is countered by an offshore-directed flow or rip current that results in rapid offshore sediment transport. On cliffed coastlines, infragravity waves may result in long period water level fluctuations at the cliff face, increased depth for short waves crossing the platform, and strong return flows transporting sediment away from the cliff toe (Beetham \& Kench, 2011). Earlie et al (2015) found that the largest contribution to clifftop motion during storm conditions is from energy at infragravity frequencies, and linked the timing of energetic cliff motion to collapse. Thus, these combined mechanisms may contribute to bluff erosion.

Sea and swell waves are typically blocked by the presence of sea ice. However, Wadhams \& Doble (2009) find that long waves ( $>20-30 \mathrm{~s}$ ) may survive up to $1000 \mathrm{~km}$ of ice cover without significant attenuation. As a result, the wave energy at ice-sheltered Arctic sites may be effectively filtered to include only low-frequency components (Squire et al., 2009).

Field measurements of nearshore wave energy and clifftop motion should be carried out to determine whether these mechanisms are relevant to erosion of frozen sediment bluffs in the Arctic. 


\section{CONCLUSIONS}

Arctic coastal dynamics are becoming more relevant as climate change progresses and human development in the north increases. To better understand the influence of changes in environmental forcing and geomorphology on coastal erosion rates at Baydaratskaya Bay, a sensitivity analysis was carried out using the COSMOS numerical model.

Key findings of this study include:

- Thermoabrasional notch erosion increases with higher water levels, larger waves, and high ice/fine sediment content

- Rapid toe retreat rates result from higher water levels, gentler bluff slopes, higher bluffs, and steeper seabed slopes.

- Larger sediment sizes and thicker active layers have a retarding effect on erosion, protecting the frozen sediment from thermoabrasion.

- Seawater temperature and salinity have a negligible influence on erosion rates when compared to the other parameters.

This study is limited by the availability of metocean and nearshore data. Without wave and water level conditions, pre- and post-storm surveys, or subsea permafrost and sediment characteristics, it was not possible to calibrate the model. Long-term, high resolution datasets on both the land and water sides of the coastline are necessary. Experimental laboratory data from physical modelling and other tests could be used to calibrate and validate numerical models of the thermal erosion process. These data gaps are the biggest roadblock to research and must be addressed prior to the further development of models.

COSMOS does not account for the gradual subaerial thawing and slope failure processes associated with thermodenudation, nor does it consider the morphological influence of sea ice in the nearshore. Nevertheless, the model's potential for use in determining relative rates of erosion for a given coastline is valuable, and may be best utilized when supplemented with additional field data.

\section{ACKNOWLEDGEMENTS}

The authors wish to acknowledge the support from the Research Council of Norway through the Centre for Research-based Innovation SAMCoT and the support from all SAMCoT partners. The authors are also grateful to Baird \& Associates for making the COSMOS model available and providing support. We would like to thank Moscow State University (MSU) for making their field data available to us for this project. S.G.P. acknowledges funding provided by the European Commission Erasmus Mundus Program.

\section{REFERENCES}

Aleksyutina, D., Brouchkov, A. \& Finseth, J., 2013. Field investigation and laboratory analyses; Baydaratskaya Bay 2013, Trondheim, Norway.

Are, F.E. et al., 2008. The Influence of Cryogenic Processes on the Erosional Arctic Shoreface. Journal of Coastal Research, 241, pp.110-121.

Are, F.E. \& Reimnitz, E., 2008. Coefficients in the Bruun/Dean Equilibrium Profile Equation Seen from the Arctic. Journal of Coastal Research, 24, pp.243-249.

Baird \& Associates, 1995. Thermal Mechanical Model for Erosion Processes on Arctic Coasts, Oakville, Canada.

Barnhart, K.R., Anderson, R.S., et al., 2014. Modeling erosion of ice-rich permafrost bluffs along the Alaskan Beaufort Sea coast. Journal of Geophysical Research: Earth Surface, 119(5), pp.1155-1179.

Barnhart, K.R., Overeem, I. \& Anderson, R.S., 2014. The effect of changing sea ice on the vulnerability of Arctic coasts. The Cryosphere Discussions, 8(3), pp.2277-2329.

Beetham, E.P. \& Kench, P.S., 2011. Field observations of infragravity waves and their behaviour on rock shore platforms. Earth Surface Processes and Landforms, 36(14), pp.1872-1888.

Belova, N.G., Solomatin, V.I. \& Romanenko, F.A., 1998. Massive Ground Ice on the Ural Coast of Baydaratskaya Bay, Kara Sea , Russia Host Sediments : Stratigraphy and Relation. In Ninth International Conference on Permafrost. pp. 107-112.

Bogorodskii, P. V. et al., 2010. Formation of fast ice and its influence on the coastal zone of the Arctic seas. Oceanology, 50(3), pp.317-326.

Church, J.A. et al., 2013. Sea level change. Climate Change 2013: The Physical Science Basis. Contribution of Working Group I to the Fifth Assessment Report of the Intergovernmental Panel on Climate Change, pp.11371216.

Couture, N.J. \& Pollard, W.H., 2007. Modelling geomorphic response to climatic change. Climatic Change, 85(3-4), pp.407-431.

Earlie, C.S. et al., 2015. Coastal cliff ground motions and response to extreme storm waves. Geophysical Research Letters, 42, pp.847-854.

Forbes, D.L., 2011. State of the Arctic Coast 2010 - Scientific Review and Outlook D. L. Forbes, ed., Geesthacht, Germany: International Arctic Science Committee, LandOcean Interactions in the Coastal Zone, Arctic Monitoring and Assessment Programme, International Permafrost Association.

Goryainov, Y.A. \& Kryjov, V.N., 2000. Baydaratskaya Bay Coastal Climate Conditions in Recent Years. In Proceedings of the Tenth (2000) International Offshore and Polar Engineering Conference. Seattle, USA, pp. 144-148.

Guégan, E.B.M. \& Christiansen, H.H., 2016. Seasonal Arctic Coastal Bluff Dynamics in Adventfjorden, Svalbard. Permafrost and Periglacial Processes, (November 2015), p.n/a-n/a.

Günther, F. et al., 2012. Thermo-erosion along the Yedoma Coast of the Buor Khaya Peninsula , Laptev Sea, East Siberia. Ticop, 2.

Harms, I.H. \& Karcher, M.J., 1999. Modeling the seasonal variability of hydrography and circulation in the Kara Sea. Journal of Geophysical Research, 104(C6), pp.13431-13448. 
Hoque, M.A. \& Pollard, W.H., 2009. Arctic coastal retreat through block failure. Canadian Geotechnical Journal, 46(10), pp.1103-1115.

Kamalov, A.M. et al., 2006. Coastal and Seabed Morpholithodynamics of the Baydaratskaya Bay at the Route of Gas Pipeline Crossing. Kriosfera Zemli (Earth Cryosphere), 10(3), pp.3-14.

Kobayashi, N. et al., 1999. Erosion of Frozen Cliffs due to Storm Surge on Beaufort Sea Coast. Journal of Coastal Research, 15(2), pp.332-344.

Kobayashi, N. \& Aktan, D., 1986. Thermoerosion of Frozen Sediment Under Wave Action. Journal of Waterway, Port, Coastal, and Ocean Engineering, 112(1), pp.140158.

Lantuit, H. et al., 2011. Coastal erosion dynamics on the permafrost-dominated Bykovsky Peninsula, north Siberia, 1951-2006. Polar Research, 30(SUPPL.1).

Lantuit, H. et al., 2012. The Arctic Coastal Dynamics Database: A New Classification Scheme and Statistics on Arctic Permafrost Coastlines. Estuaries and Coasts, 35(2), pp.383-400.

Lantuit, H. et al., 2009. Towards a calculation of organic carbon release from erosion of Arctic coasts using nonfractal coastline datasets. Marine Geology, 257(1-4), pp.1-10.

Lantuit, H., Overduin, P.P. \& Wetterich, S., 2013. Recent progress regarding permafrost coasts. Permafrost and Periglacial Processes, 24(2), pp.120-130.

Leont'yev, I.O., 2004. Coastal profile modeling along the Russian Arctic coast. Coastal Engineering, 51(8-9), pp.779-794.

Leont'yev, I.O., 2003. Modeling erosion of sedimentary coasts in the western Russian Arctic. Coastal Engineering, 47(4), pp.413-429.

Leont'yev, I.O. \& Rachold, V., 2005. Peculiarities of Coastal Evolution in the Western and Eastern Russian Arctic. In Arctic Coastal Dynamics - Report of the 5th International Workshop. pp. 76-78.

Levitan, M.A. \& Lavrushin, Y.A., 2009. Sedimentation History in the Arctic Ocean and SubArctic Seas, Berlin: Springer-Verlag.

Nairn, R.B. et al., 1998. Development and Testing of a Thermal-Mechanical Numerical Model for Predicting Arctic Shore Erosion Processes. In PERMAFROST Seventh International Conference. Yellowknife, Canada, pp. 789-795.

Nairn, R.B. \& Southgate, H.N., 1993. Deterministic profile modelling of nearshore processes. Part 2. Sediment transport and beach profile development. Coastal Engineering, 19(1-2), pp.57-96.

Nishimura, S. et al., 2009. THM-coupled finite element analysis of frozen soil: formulation and application. Géotechnique, 59(3), pp.159-171.

Ogorodov, S. et al., 2013. Ice Effect on Coast and Seabed. Geography, Environment, Sustainability, 6.3, pp.21-37.

Osterkamp, T.E. \& Romanovsky, V., 1997. Freezing of the active layer on the coastal plain of the Alaskan Arctic. Permafrost and Periglacial Processes, 8(1), pp.23-44.

Overduin, P.P. et al., 2012. Geoelectric observations of the degradation of nearshore submarine permafrost at Barrow (Alaskan Beaufort Sea). Journal of Geophysical Research: Earth Surface, 117(2), pp.1-9.

Overeem, I. et al., 2011. Sea ice loss enhances wave action at the Arctic coast. Geophysical Research Letters, 38(17), pp.1-6.
Pearson, S.G., 2015. Arctic coastal erosion - a coastal engineering perspective. Trondheim, Norway: NTNU.

Pivovarov, S., Schlitzer, R. \& Novikhin, A, 2003. River run-off influence on the water mass formation in the Kara Sea. In: Siberian River Run-Off in the Kara Sea: Characterization, Quantification, Variability, and Environmental Significance, Proceedings in Marine Science, vol. 6. Elsevier, Ams, pp, pp.9-25.

Ravens, T.M. et al., 2012. Process-Based Coastal Erosion Modeling for Drew Point, North Slope, Alaska. Journal of Waterway, Port, Coastal, and Ocean Engineering, 138(2), pp.122-130.

Rodrigues, J., 2008. The rapid decline of the sea ice in the Russian Arctic. Cold Regions Science and Technology, 54(2), pp.124-142.

Roelvink, D. et al., 2009. Modelling storm impacts on beaches, dunes and barrier islands. Coastal Engineering, 56(1112), pp.1133-1152.

Serreze, M.C. et al., 1993. Characteristics of Arctic synoptic activity, 1952-1989. Meteorology and Atmospheric Physics, 51(3-4), pp.147-164.

Simmonds, I. \& Drinkwater, M.R., 2007. A ferocious and extreme Arctic storm in a time of decreasing sea ice. In J. Côté, ed. Research Activities in Atmospheric and Ocean Modelling: Data sets, diagnostic and dynamical investigations, statistical postprocessing, multi-year reanalyses and associated studies. World Meteorological Organization, pp. 27-28.

Simmonds, I. \& Rudeva, I., 2012. The great Arctic cyclone of August 2012. Geophysical Research Letters, 39(23), pp.1-6.

Skafel, M.G. \& Bishop, C.T., 1994. Flume experiments on the erosion of till shores by waves. Coastal Engineering, 23, pp.329-348.

Southgate, H.N. \& Nairn, R.B., 1993. Deterministic profile modelling of nearshore processes. Part 1. Waves and Currents. Coastal Engineering, 19(1-2), pp.27-56.

Squire, V. a., Vaughan, G.L. \& Bennetts, L.G., 2009. Ocean surface wave evolvement in the Arctic Basin. Geophysical Research Letters, 36(22), pp.1-5.

Thomas, H.R. et al., 2009. Modelling of cryogenic processes in permafrost and seasonally frozen soils. , (3), pp.173-184.

Wadhams, P. \& Doble, M.J., 2009. Sea ice thickness measurement using episodic infragravity waves from distant storms. Cold Regions Science and Technology, 56(2-3), pp.98-101.

Wegner, C. et al., 2005. Seasonal variations in Arctic sediment dynamics - Evidence from 1-year records in the Laptev Sea (Siberian Arctic). Global and Planetary Change, 48(1-3 SPEC. ISS.), pp.126-140.

Wobus, C.W. et al., 2011. Thermal Erosion of a Permafrost Coastline: Improving Process-Based Models Using TimeLapse Photography. Arctic, Antarctic, and Alpine Research, 43(3), pp.474-484.

Wright, L.D., Guza, R.T. \& Short, a. D., 1982. Dynamics of a high-energy dissipative surf zone. Marine Geology, 45(12), pp.41-62.

Yesuf, G.Y., Hoff, I. \& Vaslestad, J., 2013. Development of excess pore-water pressure in thawing process of frozen subgrade soils: Based on analytical solutions and finite element method. In Proceedings of the 18th International Conference on Soil Mechanics and Geotechnical Engineering. Paris, pp. 857-860. 